\title{
Grassroots Women Organising for Resilient Communities around the World
}

\author{
Dahlia Goldenberg
}

\begin{abstract}
Grassroots women's organisations have, in their communities, long been organising livelihoods, assets, community space and agricultural knowledge. Their work demonstrates an 'imagining' of development different from mainstream development discourse, because it is bottom-up, self-help work. The women's ongoing strategies and new coping mechanisms serve as a foundation for community empowerment and resilience as they face the impacts of current crises. Leaders of grassroots women's community groups and NGOs that are connected through the global network of the Huairou Commission reviewed the impacts of the recent financial and food crises and of climate change on their communities. They revealed clear hardships as a result of the crises, but also questioned the emphasis on the crises, noting that donors and governments used the crises to cut funding and services. Participants instead emphasised a crisis in values and consumption patterns, where multinational corporations are tightening their grip on their lives.
\end{abstract}

\section{Summary}

Grassroots women's organisations and their partner NGOs in the global South demonstrate that women can successfully unite to carry out long-term, self-help development solutions to daily challenges and less frequent crises in their communities. This article represents reflections by women leaders from such organisations on the effects of the recent financial, food and climate crises on their communities and the coping mechanisms they use. Their coping mechanisms and long-term self-help development work suggest that they have been reimagining development since long before the crises of 2009 .

The concept of a crisis is nothing new or exceptional to these women, with their expectations of an already crisis-filled world, but they do indicate that the current crises affect their lives significantly. From decreased harvests to rising prices for basic needs, to new struggles in their small businesses, women see their livelihoods being challenged by the effects of climate change, the global food crisis and the power of large corporations.

The women in the study are leaders of local and national networks of grassroots groups (self-help groups or cooperatives) and local women's NGOs in a diverse set of countries, who are all a part of the Huairou Commission. The Huairou Commission is a global membership and partnership coalition that empowers grassroots women's organisations to exchange knowledge, enhance their local development work and construct a collective voice in global policy debates and decision-making spaces.

This research is based on Reimagining Development focus group discussions and interviews. ${ }^{1}$ This article also draws on the sharing of practices and group analysis that took place as part of a global grassroots conference, known as the 'Grassroots Academy', held in Rio de Janeiro in March 2010, as well as case studies on resilience and focus group discussions on food security, held in 22 countries. $^{2}$

Most of the 'grassroots leaders' who participated in this study live in the same community as the other members of their group, and their own lives and livelihoods are affected by the crises discussed here. They benefit directly from the organising work they carry out and the community development they achieve. The women NGO leaders in this study all work on a daily basis with 
grassroots women's groups, while they lead more of a middle-class life and have higher levels of formal education than the grassroots leaders. Most of the women participating directly in the study are middle-aged.

\section{Some limitations on focusing on 'the crises' (financial crisis, food crisis and climate change)}

Grassroots and NGO women leaders perceive a major impact in their lives from the changing climate, financial crisis and food crisis, yet they do not think these crises adequately explain the challenges their communities face. In fact, the concept of crisis may distract from the power gains that large corporations are making over markets and people's daily consumption patterns, and it may distract from political systems that continue to exclude grassroots women.

Participants suggested that donors and governments may be using the current context of crisis as a convenient sounding alarm, enabling them to continue preset agendas of reducing funding, services or programmes; most salient for some feeling let down politically by their leftist governments in Ecuador, El Salvador and Bolivia that have not brought desired changes. An Ecuadorian indigenous leader, Diocelinda Iza, said this year has been worse than recent years, 'because there is an economic and political crisis. We arrived with a lot of political hope, but we have lost it. We have the first constitution in the world that recognised a good quality of life for all but it did not bring change' (Reimagining Development Focus Group 2010).

Women feel they are being pushed to purchase in the market (often imported foods) rather than produce. Rural producers say this push exacerbates the lack of support to add value to their products before taking them to the market. Focus group discussions revealed examples of large agribusinesses asserting their power over natural resources.

Some participants perceive a resulting values shift, with less solidarity in the form of sharing resources and food among family and neighbours. Their experience as women showed a focus on wellbeing that related to more than simply sufficient consumption. Women from Ethiopia, South Africa, Cameroon and Peru all commented on this values shift in their food security focus group discussions.

\section{Perceptions of the financial crisis}

The women in the focus group discussions attributed recent increases of financial hardship related to organisational resources, daily consumption and credit to the crisis.

Some groups have found that less donor funding is available. One network leader reflected perceptions shared by many, pointing out that when recessions occur in Northern countries, this impacts their development aid priorities. For example, 'donors pull out of Brazil and all of a sudden no-one has money to do their work or it's defined in narrow, donor mandated terms. Grassroots women are used to this challenge, but it will get worse' (Sandy Schilen, at the Grassroots Academy 2010). Latin American participants see that donors are pulling out of the region, except for countries with exceptional poverty rates, such as Haiti. This response ignores wide gaps and pockets of extreme poverty in countries with strong growth. Personal resources for community organising is also reduced. Women in rural Ecuador and in Jamaica say that members of their groups are participating in fewer community meetings because of the increased urgency to stay home to care for animals and crops in Ecuador, and because of scarce funds for phone calls and transportation in Jamaica.

Focus group participants noted rises in the cost of public services as well as increased power outages and water shortages. As women, they particularly feel the impact on household budgets. In Lima, Peru, women said that people now buy less and cut off non-essential services such as the internet. A Jamaican participant lamented that a muchneeded government programme that provided free breakfast to children in need had been cut. Participants from nine countries in sub-Saharan Africa experienced a rise in the cost of agricultural inputs.

The two Peruvian women interviewed from an urban network of women's communal banks noted an increase in indebtedness due to predatory lending. Their small businesses are losing profit as customers lose acquisition power. A reduction in remittances from Peruvians working abroad and job loss due to factory closures also impacts their client base. Meanwhile, the cost of groceries for a basic lunch has doubled since the crisis began. The women bankers now take loans for small expenditures, such as Christmas gifts rather 
than business expansion or housing improvements (Olivera and Loayza 2010). Here, a group of women with long-term visions for their families and communities are now stagnating - quite the opposite of reimagining development.

\section{Recent changes affecting food production and livelihoods}

The majority of women participating in the food crisis discussion groups in 28 countries in Asia, Latin America and Africa confirmed in mid-2009 that people were eating fewer meals and less food, particularly meat.

The effects of climate change and the food crisis are affecting food production and livelihoods in several ways. Droughts and unpredictable weather stymie smallholder farmers' production, which is sometimes exacerbated by large agribusiness and other powerful business interests. Several women from small business entrepreneur groups in the study noted the power of multinationals and large businesses to dominate the value-added process to take products to market. Women from rural groups noted less rain and the drying up of streams that provided water for consumption and agriculture. Women smallholder farmers from nine countries in sub-Saharan Africa observed less predictability of rain and more extreme weather. Concurrently, struggles for ownership and control over natural resources are taking place.

For example, Diocelinda Iza, a leader of indigenous rural communities in the province of Cotopaxi in Ecuador, told of two poor, rural communities whose water sources have dried up. The residents there have all left. Despite this already extreme circumstance, the water problem is exacerbated by a nearby large-scale broccoli plantation that has used a chemical process to dissipate clouds, reducing the natural rainfall on which the two communities depend. ${ }^{3}$

\section{Reimagining development from the perspective of community women: local organising strategies with global linkages}

Traditional development frameworks tend to come out of large, professional development institutions. They often fail to recognise the work that women in their own communities carry out to pressure for basic services, provide the first response after disasters before the recognised aid organisations arrive or to develop savings and credit without support from large microfinance institutions.
In this context, grassroots women's development work has always existed as a reimagining of development - one in which community women are empowered to come up with their own solutions and their own development frameworks that are not based on solutions brought in by outside mainstream development institutions. Their work is not informed by high-level research projects or economic theories, but by their own lived experiences and by trial and error methods to enhance wellbeing. The work of grassroots women's organisations is not a new solution to a new problem; rather their work represents ongoing processes by women over time - often 10-20 years, to respond to poverty and local or national crises.

During the current crises, their ongoing work sometimes stagnates (as in the case of the businesses and loans suffering in the Peruvian communal banks network), but even in these cases, the social network of their organisations remains indispensable to maintaining the development visions they have put in practice for many years.

Has this crisis brought about a new way of envisioning development for these women? Women's groups presented a few new ways of coping with food insecurity but in general, this study did not find any major innovations or reimaginings coming out of the crisis. However, their ongoing organising strategies of claiming financial assets, communal space and political power continue to form the bedrock for the survival of their organisations and their development successes.

The sustained strength of their organisations represents the flip side of the bleak picture that the women cited in their disappointments with national political leaders and reduced support from donors and governments. They continue to contribute to development in hard times, while governments and donors sometimes fail to match their efforts. When women are made to bear this burden, it is in some ways a result of sexism and expectations of women in their rigid gender roles, but much more so, it is a demonstration of women's personal and collective capacity and power which can be wielded to make more structural political changes. 


\subsection{Women claim financial assets through collective processes to improve their lives and form ongoing support networks}

Grassroots women's groups around the world have long used a variety of collective savings and credit schemes that reflect a more holistic and future-looking model of development than that of popular international microcredit institutions and NGOs that narrowly focus on economic empowerment. Autonomous and financially viable, these grassroots networks in Bolivia, Guatemala, India, Nepal and Peru build women's political power for development and provide social cohesion and economic stability.

Groups of women initially come together to improve their economic situation but eventually broaden their collective power to lobby local governments for basic services, infrastructure and housing or to achieve formal political participation. The Nepalese women point to their ongoing savings and cooperatives as a 'backbone' for coping with the food crisis, as prices for agricultural inputs would otherwise be out of reach (LUMANTI 2009). Guatemalan and Bolivian rural indigenous women's groups report that in light of the food crisis, they are strengthening their savings groups and pushing themselves to continue contributing to them. Participants from Benin, Ethiopia, Ghana, Kenya and South Africa also continued their savings and credit schemes during the food crisis.

\subsection{Women claim public space}

When organisational funding dries up or other crises hit and if the organisation owns its centre, it can continue at least some of its work and maintain its role in the community. In Nicaragua, Cameroon and Sri Lanka, women claimed public space and organised for long-term sustainability by building their own community centres. The centres are indispensable resources - women from nearby communities meet there regularly, and centres serve as shelters during disasters. Women also use their centres to increase their power, inviting officials into their own space for dialogue with them.

\subsection{Exchanging knowledge for improved agriculture practices}

Many groups in the study indicate that knowledge exchange and reclaiming values among peer groups of women is key to sustaining their local development work, particularly in agricultural production during times of changing climatic patterns.

In Cameroon, the Ntankah Village Women Common Initiative Group developed a 'Mother's Centre' to care for children, but the centre now serves to share information and documentation, provide internet access and hold workshops for women. As a result of their work, women farmers have enhanced awareness of sustainable agriculture practices that protect the environment, natural resources and soil fertility. At the same time, they are improving the marketability of their products (Fordham et al. 2010). They reduced the use of the slash-andburn method and taught soil management, land preparation, composting and other sustainable agricultural skills to 150 women.

In Guatemala, indigenous rural women's groups teach other women about organic gardening practices, in effect re-educating their communities on traditional values and farming practices in relation to the environment. This community self-education validates local knowledge and builds self-reliance at a time when extension services from the government are non-existent.

\subsection{Women work collectively to maintain and improve agricultural production in times of crisis}

Rural communities in Kenya and Ghana have instituted food banks as a preventative measure for months of famine. Surplus yields are placed into storage facilities for later use by contributing families, and from this supply, the neediest families in the community are allocated portions (GROOTS Kenya 2009; Grassroots Sisterhood Foundation 2009). One group in Kenya mobilised local families to identify a plot for a nutritional field school, specifically to support each other to cope with the recent food and financial crisis.

In Shikwa, an Indian group connected with the NGO Swayam Shikshan Prayog, 500 women organised organic vegetable cooperatives in 20 different villages. They share production methods and negotiate with village leaders and the Department of Agriculture to acquire technical training. In a series of local discussion forums, the women expressed the need to continue developing their own leadership as women in their communities and to spread their 
work to other villages in order to cope with the ongoing food crises, climate change and poverty (Ibarra and Silliman 2010: 11).

\section{Conclusions}

For these women, a reimagination of development is one in which they play a key leadership role, but this role must be recognised and resourced. As we can see from the organising practices shared here, community women leaders have been reimagining local development for a long time. Their processes and structures prove particularly useful in times of crisis, by sharing agricultural knowledge, collectively storing food or ensuring contributions to grassroots financial mechanisms for the future. The Huairou Commission's partnership work connects these groups through collective processes with a diverse set of international development institutions including the UN, research institutions and bilateral agencies. The work is one example of how grassroots organising practices can gain recognition and influence at the global level.

Although these groups have survived as strong organisations and come up with some useful coping mechanisms, they have not as yet developed, in relation to the crises addressed in the Reimagining Development research, the kind of innovations or organisational growth that emerged from other crises. Grassroots women's movements have emerged from crises in the past. For example, popular kitchens emerged in Peru

\section{Notes}

1 Two focus group discussions and two interviews were carried out with a total of 21 leaders of grassroots women's networks and NGOs that are Huairou Commission member groups. The author led the focus group discussions and interviews as a part of the Reimagining Development initiative.

2 In autumn 2009, 22 grassroots organisations, affiliated with the Huairou Commission in different countries, held focus group discussions with women in their community organisations in order to reflect on the food crisis, its impacts on their lives and the coping mechanisms and responses their organisations had to the crisis. The focus group discussions during an economic crisis in the late $1970 \mathrm{~s}$ (Kamioka 2001) and then grew into a social movement of poor women that continues today. Also, the crises of national disasters spurred much of the work on disaster recovery and mitigation, political participation, livelihoods and food security by other grassroots women's organisations affiliated with the Huairou Commission in Honduras, India and Turkey that continues strongly today (Yonder et al. 2005). It remains to be seen whether new innovations will emerge in the future if and when impacts of the present crises become more severe.

Many of the grassroots women in this study pointed out peer learning opportunities as a priority for their own work. They want to gain more elected positions and hold their governments accountable to commitments such as the Millennium Development Goals (MDGs). They said that governments must put in place policies and mechanisms for recognising the work of grassroots women's organisations in contributing to development, by allocating budgetary funds for women's small businesses, production cooperatives and access to markets. The women argued that donors should insist on fewer conditions and fund communities directly.

Finally, in a statement that captures the essence of this study, a few women said that donors must use the opportunity of this crisis to listen more carefully to stories from communities.

were made as part of a project carried out by the Huairou Commission, with the support of the United Nations Food and Agriculture Organization (FAO) and Women Organizing for Change in Agriculture and Natural Resource Management (WOCAN). The results of these focus group discussions are shared broadly throughout this article. A full list of the focus group discussions can be found in the Annex at the end of this article.

3 A local news report confirms the problem and the community's efforts to ensure the broccoli farm complies with environmental and health standards (El Comercio, www.elcomercio.com/ Generales/Solo-Texto.aspx?gn3articleID= 194847). 


\section{References}

Fordham, M.; Gupta, S.; Akerkar, S. and Scharf, Manuela (2010) Leading Resilient Development: Grassroots Women's Priorities, Practices and Innovations, GROOTS International and Gender Team, Bureau for Policy Development, UNDP

Grassroots Sisterhood Foundation (2009) Consultation on Food Security, Accra: Grassroots Sisterhood Foundation

GROOTS Kenya (2009) A Grassroots Consultation on Food Security and Climate Change Towards the World Summit on Food and Security, Nairobi

Ibarra, K. and Silliman, S. (2010) 'The Huairou Commission MDG 3 Accountability Initiative: Centre-Staging Grassroots Women in Realizing the MDGs', The Grassroots Challenge Grants Forum, Huairou Commission, New York City, www.huairou.org/sites/default/files/Challenge _Grant_FINAL.pdf (accessed 28 July 2011)

Kamioka, Naoko (2001) Women's Voluntary Groups in Lima, Peru: Comedores Populares', Washington DC: World Learning, www.mef.gob.pe/ contenidos/pol_econ/documentos/C_Populares _N_Kamioka.pdf (accessed 29 April 2011)

LUMĀNTI (2009) Grassroots Consultation Towards the World Summit on Food Security: Focus Group Discussions in Khokana, Thankot, Thecho, Tokha, Kathmandu

Olivera, Maura and Loayza, Ana (2010) interview, 25 March, transcript in possession of author

Yonder, A.; Akcar, S. and Gopalan, P. (2005) 'Women's Participation in Disaster Relief and Recovery', SEEDS 22

\section{Annex: Focus Group Discussions}

Asia Farmers Association (2009) 'Grassroots Consultations on Climate Change and Food Security'

AWARE (2009) 'Grassroots Consultation Towards the World Summit on Food Security'

Centro de Mujeres Aymaras, Candelarias (2009) 'Seguridad Alimentaria: Preguntas de Grupos de Enfoque' [Candelarias Aymara Women's Center (2009) 'Food Security: Focus Group Questions']

CODIMM (2009) 'Preguntas y Respuestas de los tres Grupos Focales Participantes en Seguirdad Alimentaria' [CODIMM (2009) 'Questions and Answers from the Three Participating Focus Groups in Food Security']

Comite de Emergencia Garifuna (2009) 'Preguntas y Respuestas de los Tres Grupos
Focales Particpantes en Seguirdad Alimentaria' [Garifuna Emergency Committee (2009) 'Questions and Answers from the Three Participating Focus Groups in Food Security']

CONAMOVIDI (2009) 'Consulta de Base para la Cumbre Mundial en Seguridad Alimentaria' [CONAMOVIDI (2009) 'Grassroots Consultation for the World Summit on Food Security']

FEMUM (2009) 'Informe Mujeres Campesinas' [FEMUM (2009) 'Women Farmers Report']

Grassroots Sisterhood Foundation (2009)

'Consultation on Food Security'

GROOTS Jamaica (2009) 'Grassroots Consultation on Food Security'

GROOTS Kenya (2009) 'A Grassroots Consultation on Food Security and Climate Change Towards the World Summit on Food and Security'

Himalayan Grassroots Women's Natural Resource Management Association (HIMAWANTI) (2009) 'Focus Group Findings'

India CCD (2009) 'Grassroots Consultation Towards the World Summit on Food Security', in Balangir District Branch, Orissa State, Sheopur District Branch, MP State, Tamilnadu State

Katuba Women's Association (2009) 'Report on Community Consultative Meetings held in Katuba Constituency'

Lambassa ICA (2009) 'Consultations with Grassroots Women for the World Summit on Food Security'

LUMANTI (2009) 'Thankot Women Saving and Credit Cooperative Ltd', 'Thecho Women Saving and Credit Cooperative', Khokana Focus Group Discussion

Luna Greciente (2009) 'Consulta de Base para la Cumbre Mundial sobre Seguridad Alimentaria' [Luna Creciente (2009) 'Grassroots Consultation for the World Summit on Food Security']

Maasai Women Development Organization (MWEDO) (2009) 'Focus Group Grassroots Consultation Towards the World Summit on Food Security'

Mary Joy Aid Through Development (2009) 'Consultation on Food Security'

Ntankah Women of Cameroon (2009) Five focus group discussion reports

Red Pintadas (2009) 'Consultation on Food Security' 
Reimagining Development Focus Group (2010) Discussion No 2, 16 March, transcript in possession of author

Swayam Shikshan Prayog, Maharashtra (2009) 'Food Security'

Union de Cooperativas, Las Brumas (2009)

'Consulta de base para la Cumbre Mundial en Seguridad Alimentaria, Efectos de la Crisis

Alimentaria en el Hogar, la Familia y la
Comunidad' [Union of Cooperatives, Las Brumas (2009) 'Grassroots Consultation for the World Summit on Food Security, Effects of the Food Crisis on the Home, Family and Community'] 